\author{
Marquette University \\ e-Publications@Marquette
}

Spanish Languages and Literatures Research

Languages, Literatures and Culture Faculty and Publications

Research and Publications

Winter 2010

\title{
The Relationship Among Motivation, Interaction, and the Development of Second Language Oral Proficiency in a Study- Abroad Context
}

Todd A. Hernández

Marquette University, todd.hernandez@marquette.edu

Follow this and additional works at: https://epublications.marquette.edu/span_fac

Part of the Spanish and Portuguese Language and Literature Commons

\section{Recommended Citation}

Hernández, Todd A., "The Relationship Among Motivation, Interaction, and the Development of Second Language Oral Proficiency in a Study-Abroad Context" (2010). Spanish Languages and Literatures Research and Publications. 27.

https://epublications.marquette.edu/span_fac/27 
Marquette University

e-Publications@Marquette

\title{
Spanish Languages, Literatures and Cultures Faculty Research and Publications/College of Arts and Sciences
}

This paper is NOT THE PUBLISHED VERSION; but the author's final, peer-reviewed manuscript. The published version may be accessed by following the link in the citation below.

Modern Language Journal, Vol. 94, No. 4 (Winter 2010): 600-617. DOI. This article is (C) Wiley and permission has been granted for this version to appear in e-Publications@Marquette. Wiley does not grant permission for this article to be further copied/distributed or hosted elsewhere without the express permission from Wiley.

\section{The Relationship Among Motivation, Interaction, and the Development of Second Language Oral Proficiency in a Study-Abroad Context}

\author{
Todd A. Hernández
}

Marquette University, Foreign Languages and Literatures, Milwaukee, WI

\footnotetext{
Abstract

The purpose of this investigation was to examine the role of integrative motivation, instrumental motivation, and interaction with a second language (L2) culture in shaping students' speaking performance before and after participation in a 1-semester study-abroad program in Spain. A 2-part questionnaire (Student Background Information and Motivation Index), a language contact profile, and a pretest and posttest simulated oral proficiency interview were administered to 20 study-abroad participants. The results highlight 3 major points. First, students can indeed improve their L2 speaking proficiency during a 1-semester study-abroad program. Second, there is a positive relationship between students' integrative motivation and their interaction with the
} 
L2 culture. Third, student contact with the Spanish language has a significant effect on their speaking improvement. The data confirm the importance of focusing on learning activities that enhance students' integrative motivation and interaction with the L2 culture in both the formal classroom ("at home") and in the study-abroad program.

The study-abroad experience for language learning is a subject of increasing importance in foreign language education. A number of recent studies have investigated the development of oral proficiency (Brecht, Davidson, \& Ginsberg, 1993, 1995; Freed, 1995; Magnan, 1986; Magnan \& Back, 2007; Segalowitz \& Freed, 2004), the use of communication strategies (Lafford, 1995, 2004), and the acquisition of grammatical (Collentine, 2004; Duperron, 2006; Isabelli, 2004, 2007), pragmatic (Barron, 2003; Cohen \& Shively, 2007; Magnan \& Back, 2006; Rodríguez, 2001), and sociolinguistic competence (Barron, 2006; Regan, 1995, 2003). Research has also examined the development of narrative (Collentine, 2004) and phonological abilities during study-abroad programs (Díaz-Campos, 2004, 2006), as well as student perceptions of the study-abroad experience (Brecht \& Robinson, 1995; Douglass, 2006; Kinginger, 2008; Miller \& Ginsberg, 1995; Wilkinson, 1998, 2002). Together, these studies have provided the second language (L2) teaching profession with critical information on how specific language features develop in a study-abroad context and which external and internal factors seem to promote language development. They also suggest optimal time periods for study-abroad program participation.

The present investigation sought to expand this research agenda. It examined how motivation and contact with the $L 2$ interact to shape students' speaking performance before and after participation in a one-semester studyabroad program. This is one of the few studies to address the connections among student motivation, interaction with the $L 2$, and speaking improvement on a performance-based speaking test such as a simulated oral proficiency interview (SOPI; Center for Applied Linguistics, 1995). As such, the results of this study contribute to the development of explicit teaching strategies and recommendations for learning activities in both study-abroad programs and formal college, or "at-home," instruction.

\section{BACKGROUND}

\section{Motivation}

Much of the research addressing the effect of motivation on L2 learning has focused on integrative and instrumental motivation. ${ }^{1}$ Gardner and Lambert (1959) identified integrative motivation as (a) an interest in learning the $L 2$ in order to interact with the L2 group as well as (b) positive attitudes toward the native speakers (NSs) of this group and their culture. Instrumental motivation, in contrast, was defined as an interest in learning the $\mathrm{L} 2$ in order to attain a pragmatic objective, such as to enhance future career opportunities. Within this framework, researchers have found integrative motivation an important factor in predicting student success in the L2 classroom (Dörnyei \& Clément, 2000; Dörnyei \& Schmitt, 2001; Ely, 1986; Gardner, 1985, 2000; Gardner \& Lambert, 1972; Hernández, 2006; Masgoret \& Gardner, 2003). Gardner and Lambert (1972) discovered a positive relationship between integrative motivation and the language achievement of students of French as an L2. Ely (1986) further investigated the use of the integrative and instrumental motivation paradigm for students of Spanish as an L2. His factor analysis of student responses to a questionnaire confirmed the existence of three motivation factors: (a) integrative motivation, (b) instrumental motivation, and (c) motivation provided by the need to fulfill the foreign language requirement. Ramage (1990) examined the relationship between motivation and the desire to continue to enroll in French or Spanish courses after completing the second year of high school. She discovered a positive relationship between interest in the $L 2$ culture and intent to continue studying French or Spanish. Dörnyei and Clément (2000) identified integrative motivation as the most important component in determining a student's level of effort and investment in the language learning process. Research has also found a positive relationship between integrative motivation and L2 oral proficiency (Hernández, 2006). 


\section{Student Interaction With the L2}

In comparing language learning in a formal college classroom (at home) to a study-abroad environment, it is often assumed that study abroad is superior to instruction at home because the study-abroad experience offers students greater access to NSs and more varied opportunities to use the target language as a tool for exchanging information and participating in social and interpersonal functions (Batstone, 2002; Collentine \& Freed, 2004; Lafford \& Collentine, 2006; Segalowitz \& Freed, 2004). As a result, recent research on the effect of study abroad has focused on the role of student interaction with NSs in fostering L2 acquisition (Ginsburg \& Miller, 2000; Lapkin, Hart, \& Swain, 1995; Magnan \& Back, 2007; Regan, 1995; Segalowitz \& Freed, 2004). Numerous researchers have argued that frequent and sustained interaction is an important predictor of language improvement in a study-abroad context (Collentine \& Freed, 2004; Freed, 1995; Meara, 1994; Segalowitz \& Freed, 2004). Both Lapkin et al. (1995) and Regan (1995) found that student contact with NSs contributed to language gain. Ginsburg and Miller (2000), however, in examining how students' use of Russian shaped the development of their speaking proficiency, did not find a relationship between Russian-mediated language activities and speaking improvement. Segalowitz and Freed (2004) compared the speaking proficiency of studyabroad participants in Spain with that of students in an at-home learning environment in the United States. The results did not reveal a significant relationship between student contact with the Spanish language and gains on an oral proficiency interview (OPI) that was administered as a pretest and posttest. Similarly, Magnan and Back (2007) discovered that although speaking improvement is possible during a one-semester study-abroad program, social interaction with French speakers did not predict student gains in speaking proficiency. Based on the results of a postprogram questionnaire, the authors argued that some study-abroad participants might not have invested sufficient time in the kinds of social relationships with French speakers that were needed to support sustained speaking improvement.

Several recent studies on the effect of the study-abroad context have begun to supplement quantitative methods of investigation with qualitative approaches. Isabelli-García (2006) assessed the role of attitudes, motivation, and social interaction on the speaking performance of four study-abroad participants in Buenos Aires, Argentina. The students took pretest and posttest SOPIs to measure their speaking improvement. Diaries, questionnaires, and social network logs also provided data on the students' attitudes, their motivation, and the amount of their social interaction with NSs of Spanish. The results indicated a positive relationship between student interaction with NSs and the development of speaking proficiency after participation in the onesemester study-abroad program. Isabelli-García also found that motivation had a significant effect on student interaction with the L2 culture. One male participant in her study, who experienced a pretest to posttest SOPI gain of +1 , demonstrated a high integrative motivation to study Spanish and understand the new culture. His learner profile suggested that his positive attitudes and high motivation were important factors in his development of social networks with Argentines and his concurrent progress in L2 acquisition.

Kinginger (2008) examined the case histories of study-abroad participants in France seeking insight into the sources of the significant individual differences in L2 achievement often found in study-abroad research. Combining the students' personal accounts of their study-abroad experiences with documentation of their learning outcomes, Kinginger sought to understand 'the relationship among the participants' histories as American foreign language learners, the nature of their investment in language learning, the qualities of their experience, and documented outcomes" (p. 13). She collected data through interviews, journal entries, on-site observations, and pretest and posttest language assessments. As in previous studies, her results indicated that the study-abroad environment was both productive and imperfect for the development of $L 2$ communicative competence (p. 107). She found that student engagement in L2 learning in the study-abroad context was shaped by complex interactions among their identities, actions, perceptions, and the resources of host communities ( $p$. 13). 
Prior to Isabelli-García's (2006) work, Freed (1990) authored one of the few studies to investigate the impact of motivation and interaction with the L2 culture on the speaking proficiency of students in a study-abroad context. Freed's participants were 40 undergraduate students in a 6-week study-abroad program in France. The students completed a questionnaire to assess their attitudes and motivation toward French language studies. They also took the College Examination Board Language Achievement Test and an American Council on the Teaching of Foreign Languages (ACTFL) OPI as pretests and posttests to measure the gains in their grammar and reading comprehension skills. Language contact profiles (LCPs), diaries, interviews, and observations provided estimates of the students' contact with the French language outside of the classroom. Freed, however, counter to expectations, found no evidence of a significant relationship between student motivation and interaction with NSs. Her results also indicated that there was no connection between student interaction with NSs and speaking scores. She suggested that the effect of interaction with NSs on the students' speaking performance might have been more evident in a one-semester or longer study-abroad program than in the shorter 6-week program used in her research.

With the exception of Freed's (1990) and Isabelli-García's (2006) work, few studies have examined how student motivation and contact with the target language interact to foster L2 acquisition in a study-abroad context. At the same time, research has suggested that integrative motivation is an important predictor of $L 2$ learning (Dörnyei \& Clément, 2000; Dörnyei \& Schmitt, 2001; Gardner, 1985, 2000; Masgoret \& Gardner, 2003).

Researchers have also argued that the study-abroad context might enhance the effect of integrative motivation on L2 achievement (Oxford \& Shearin, 1994). The present study, therefore, addresses the relationship between motivation and interaction with the L2 on the development of L2 speaking performance in a study-abroad environment.

\section{RESEARCH QUESTIONS}

The five research questions addressed in the present study were as follows:

1. Do study-abroad students demonstrate integrative and instrumental motivation to study Spanish as an L2?

2. To what extent do study-abroad students use their L2 outside of class?

3. Do study-abroad students improve their $\mathbf{L} 2$ oral proficiency after participating in a one-semester studyabroad program?

4. Does motivation predict the amount of student interaction with the L2 culture?

5. Does the amount of student interaction with the $L 2$ culture relate to gains in $L 2$ oral proficiency after participation in a one-semester study-abroad program?

\section{METHODOLOGY}

The present study used a pretest and posttest design to examine the relationships among motivation, interaction with the $L 2$, and $L 2$ speaking proficiency in a group of study-abroad participants in Spain.

\section{Participants}

The participants in the present study consisted of 20 students from Marquette University who participated in a one-semester study-abroad program in Madrid, Spain, in the spring semester of 2008. The four criteria for a student's participation in the program were that he or she (a) spoke English as a native language, (b) had a minimum of four semesters of formal instruction in Spanish as an L2, (c) did not speak Spanish at home, and (d) was obligated to complete all pretest and posttest questionnaires and interviews. 
Of the participants, 4 were male $(20 \%)$ and 16 were female $(80 \%)$. Their ages ranged from 18 to 21 years $(M=$ $19.80, S D=0.83$ ). Their prior language experience varied from 2.5 to 7.5 years of formal instruction in Spanish at the secondary and postsecondary levels. Their cumulative grade point averages ranged from 2.60 to $3.80(M=$ $3.47, S D=0.32)$. Out of the 20 students, $16(80 \%)$ reported living with host families and 4 students (20\%) lived in apartments with roommates from the United States (see Appendix A for further participant information).

All of the participants completed a 3-week orientation course in Spain at the beginning of their study-abroad program. The purpose of this orientation was to provide them with opportunities to practice their L2 skills prior to participating in regular classroom instruction. The course consisted of 24 classroom hours of language instruction with an emphasis on developing L2 speaking and listening abilities. The students also received lectures on Spanish art, politics, and cultural differences between the United States and Spain, as well as a general introduction to life in Madrid. After the orientation program, the study-abroad program participants enrolled in four or five courses through Reunidas (a consortium of courses designed for U.S. students and offered by Spanish professors from the Universidad de Complutense de Madrid). Students also had the option of taking at least one course from the regular curriculum of the Complutense in which they would be integrated with Spanish students.

\section{Instrumentation}

Student Questionnaire All students completed a questionnaire (see Appendix B) in the first week of December 2007, prior to participating in the study-abroad program in Spain. The questionnaire consisted of two parts: (a) Student Background Information and (b) the Motivation Index. The first part of the questionnaire asked about the students' genders, ages, academic majors, grade point averages, and prior language experience. The second part, adapted from Ely (1986) and Gardner (1985), contained two subscales: (a) an Integrative Motivation scale and (b) an Instrumental Motivation scale. Using a 4-point Likert-type scale, the participants indicated the extent to which different reasons for studying Spanish were important to them.

Simulated Oral Proficiency Interview To assess gains in L2 speaking abilities, a 45-minute SOPI was administered to all participants as a pretest in the second week of December of 2007 prior to their departure for Spain. The students took the posttest SOPI in Spain at the end of the spring semester (in the second week of May 2008). The Spanish SOPI, $\underline{\underline{2}}$ available from the Center for Applied Linguistics, is a performance-based, tape-mediated test of speaking proficiency. As with the ACTFL OPI, the purpose of the SOPI is to elicit speech samples that are rated according to the ACTFL Proficiency Guidelines (ACTFL, 1999). The SOPI uses an audiotape and printed test booklet to obtain a speech sample from the examinee instead of the face-to-face interview procedure that is used for the OPI. During an SOPI, the examinee listens to a series of speaking tasks on a master tape and records his or her responses on a blank cassette. A global rating is assigned by comparing the examinee's responses with the criteria in the Guidelines. The SOPI for the present study consisted of a warm-up section and 15 speaking tasks. In the warm-up, the students answered questions in a simulated conversation with a native Spanish speaker and then responded to 15 performance-based speaking tasks. The speech functions and ACTFL OPI levels of these tasks are presented in Table 1.

Table 1. Format of Simulated Oral Proficiency Interview

\begin{tabular}{|l|l|}
\hline Speech Function & ACTFL Level \\
\hline Warm-Up & Novice-Intermediate \\
\hline Asking Questions & Intermediate \\
\hline Describing Activities & Intermediate \\
\hline Giving Directions & Intermediate \\
\hline Narrating in the Present Time & Advanced \\
\hline Narrating in the Past Time & Advanced \\
\hline
\end{tabular}




\begin{tabular}{|l|l|}
\hline Discussing Personal Activities & Intermediate \\
\hline Explaining a Process & Advanced \\
\hline Stating Advantages and Disadvantages & Advanced \\
\hline Supporting an Opinion & Superior \\
\hline Hypothesizing on an Impersonal Topic & Superior \\
\hline Speaking with Tact & Advanced \\
\hline Speaking to Persuade Someone & Superior \\
\hline Proposing and Defending a Course of Action & Superior \\
\hline Giving a Talk & Superior \\
\hline Giving Advice & Advanced \\
\hline
\end{tabular}

The SOPI was scored by the researcher and a second rater with the assistance of the Multimedia Rater Training Program (MRTP): Spanish Version (Center for Applied Linguistics, 2006). The researcher rated the pretest and posttest SOPI tapes of all 20 participants. The second rater then scored a total of 10 of these tapes in order to establish interrater reliability. The raters agreed on 7 out of the 10 SOPI tapes. There were disagreements on three of the tapes. The raters reviewed these tapes and then assigned new scores. The percentage of absolute agreement was high (70\%), and the correlation between the two raters was also high (0.91).

Language Contact Profile A modified LCP (Freed, Dewey, Segalowitz, \& Halter, 2004) consisting of 10 items was administered to the participants at the end of their semester abroad (see Appendix C). The LCP asked the students to report the number of hours per week that they spent in speaking, reading, writing, and listening activities in Spanish outside of class. The sum of these responses provided the researcher with an estimate of each student's total amount of interaction with the $L 2$ culture.

\section{Data Analysis}

Both descriptive and inferential statistics were used to address the five research questions. The statistical procedures included the following: descriptive analysis, a paired samples $t$-test, and regression analysis. For all analyses, alpha was set at .05.

\section{RESULTS}

Research Question 1: Do Study-Abroad Students Demonstrate Integrative and Instrumental Motivation to Study Spanish as an L2?

The second part of the pretest student questionnaire consisted of two subscales: Integrative Motivation (nine items) and Instrumental Motivation (four items). When the scores on these subscales were calculated, the students' scores on the Integrative Motivation subscale (maximum score $=27$ ) ranged from 21 to 27 ( $M=$ $24.25, S D=2.05$ ) and scores on the Instrumental Motivation subscale (maximum score $=12$ ) ranged from 4 to 12 $(M=10.70, S D=1.92)$. The means and standard deviations of the individual items $s^{\underline{3}}$ on these subscales are presented in Table 2. As indicated in Table 2, the two highest ranked items were the desire to converse with Spanish speakers in the United States (Item 18; $M=2.95, S D=0.22$ ) and the desire to use Spanish for future travel (Item 17; $M=2.90, S D=0.31$ ). In contrast, the two lowest ranked items were learning Spanish in order to enhance one's résumé (Item 29; $M=2.45, S D=0.76$ ) and an interest in Hispanic literature and culture (Item $19 ; M=2.25, S D=0.72$ ).

Table 2. Means and Standard Deviations on the Motivation Index

\begin{tabular}{|l|l|l|l|l|}
\hline Item No. & Subscale & Description of Item & $\boldsymbol{M}$ & $\boldsymbol{S D}$ \\
\hline 18 & Integrative & To speak with Spanish speakers in the United States & 2.95 & 0.22 \\
\hline 17 & Integrative & To use Spanish for future travel & 2.90 & 0.31 \\
\hline
\end{tabular}




\begin{tabular}{|l|l|l|l|l|}
\hline 20 & Instrumental & Need it for future career & 2.90 & 0.31 \\
\hline 28 & Integrative & To speak with NSs in Spanish & 2.90 & 0.31 \\
\hline 22 & Integrative & To speak another language & 2.80 & 0.41 \\
\hline 24 & Instrumental & To increase employment opportunities & 2.80 & 0.52 \\
\hline 26 & Integrative & Spanish is an important language & 2.70 & 0.47 \\
\hline 23 & Integrative & To learn about another culture & 2.65 & 0.59 \\
\hline 25 & Integrative & As part of a well-rounded education & 2.60 & 0.68 \\
\hline 27 & Instrumental & To increase employment opportunities & 2.55 & 0.83 \\
\hline 21 & Integrative & To use it with Spanish-speaking friends & 2.50 & 0.51 \\
\hline 29 & Instrumental & To enhance résumé or CV & 2.45 & 0.76 \\
\hline 19 & Integrative & Interest in Hispanic literature and culture & 2.25 & 0.72 \\
\hline
\end{tabular}

Note. Items rated on a 4-point scale: 0 = not important; 1 = slightly important; 2 = moderately important; 3 = very important; $\mathrm{CV}=$ curriculum vitae; NS = native speaker.

\section{Research Question 2: To What Extent Do Study Abroad Students Use Their L2 Outside of} Class?

The LCP consisted of 10 items. The sum of these items represented the number of hours each week that the students participated in speaking, listening, reading, and writing activities in Spanish outside of class. The student responses on the LCP yielded scores ranging from 31.50 to 115.50 hours each week $(M=60.68, S D=$ 24.98). As illustrated in Table 3 , the three highest ranked items on the LCP were speaking Spanish to NSs or fluent Spanish speakers (Item $1 ; M=16.80, S D=11.56$ ), writing homework assignments in Spanish (Item 9; $M=$ 9.09, $S D=5.58$ ), and listening to Spanish music (Item 8; $M=7.53, S D=4.40$ ). The lowest three ranked items were listening to Spanish movies or videos (Item 7; $M=3.53, S D=2.85$ ), writing email in Spanish (Item 10; $M=$ 3.30, $S D=2.66$ ), and reading Spanish language magazines (Item $4 ; M=1.58, S D=2.40$ ).

Table 3. Means and Standard Deviations on the Language Contact Profile

\begin{tabular}{|l|l|r|r|}
\hline Item No. & Description of Item & \multicolumn{1}{|c|}{$\boldsymbol{M}$} & \multicolumn{1}{|l|}{$\boldsymbol{S D}$} \\
\hline 1 & Speaking Spanish with NSs & 16.80 & 11.56 \\
\hline 9 & Writing homework assignments in Spanish & 9.09 & 5.58 \\
\hline 8 & Listening to Spanish music & 7.53 & 4.40 \\
\hline 6 & Listening to Spanish TV and radio & 6.99 & 4.65 \\
\hline 5 & Reading email or Internet in Spanish & 4.38 & 2.98 \\
\hline 2 & Reading Spanish newspapers & 3.85 & 1.99 \\
\hline 3 & Reading novels in Spanish & 3.65 & 2.93 \\
\hline 7 & Listening to Spanish movies or videos & 3.53 & 2.85 \\
\hline 10 & Writing email in Spanish & 3.30 & 2.66 \\
\hline 4 & Reading Spanish language magazines & 1.58 & 2.40 \\
\hline
\end{tabular}

Note. Language contact profiles showed the number of hours per week students spent on these activities; NS = native speaker.

\section{Research Question 3: Do Study-Abroad Students Improve Their L2 Oral Proficiency After} Participating in a One-Semester Study-Abroad Program?

Student pretest and posttest SOPI performances were assigned a rating on the ACTFL Proficiency Scale. These ratings were then converted into numerical values for the purpose of data analysis: from novice low 1 to superior $=10$. The students' pretest and posttest SOPI scores are presented in Tables 4 and $\underline{5}$.

Table 4. Means, Standard Deviations, Frequencies, and Percentages on the Pretest SOPI $(N=20)$ 


\begin{tabular}{|l|l|l|l|}
\hline ACTFL Oral Proficiency Level & Assigned OPI Value & Frequency & Percentage \\
\hline Superior & 10 & & \\
\hline Advanced High & 9 & & \\
\hline Advanced Mid & 8 & & \\
\hline Advanced Low & 7 & & \\
\hline Intermediate High & 6 & 3 & $15 \%$ \\
\hline Intermediate Mid & 5 & 15 & $75 \%$ \\
\hline Intermediate Low & 4 & 2 & $10 \%$ \\
\hline Novice High & 3 & & \\
\hline Novice Mid & 2 & & \\
\hline Novice Low & 1 & & \\
\hline Total & & 20 & $100 \%$ \\
\hline
\end{tabular}

Note. $M=5.05, S D=0.51 ; \mathrm{OPI}=$ oral proficiency interview; $\mathrm{SOPI}=$ simulated oral proficiency interview.

Table 5. Means, Standard Deviations, Frequencies, and Percentages on the Posttest SOPI ( $N=20)$

\begin{tabular}{|l|l|l|l|}
\hline ACTFL Oral Proficiency Level & Assigned OPI Value & Frequency & Percentage \\
\hline Superior & 10 & & \\
\hline Advanced High & 9 & & \\
\hline Advanced Mid & 8 & & \\
\hline Advanced Low & 7 & 8 & $40 \%$ \\
\hline Intermediate High & 6 & 6 & $30 \%$ \\
\hline Intermediate Mid & 5 & 6 & $30 \%$ \\
\hline Intermediate Low & 4 & & \\
\hline Novice High & 3 & & \\
\hline Novice Mid & 2 & & \\
\hline Novice Low & 1 & & \\
\hline Total & & 20 & $100 \%$ \\
\hline
\end{tabular}

Note. $M=6.10, S D=0.85 ; \mathrm{OPI}=$ oral proficiency interview; SOPI = simulated oral proficiency interview.

Table 4 shows that prior to participating in the one-semester study-abroad program, 2 students (10\%) out of the 20 participants received a rating of intermediate low, 15 students $(75 \%)$ received a rating of intermediate mid, and 3 students (15\%) were rated intermediate high.

Posttest SOPI scores ranged from intermediate mid to advanced low. Table 5 reveals that after the study-abroad experience, 6 students (30\%) received a rating of intermediate mid, 6 students (30\%) received a rating of intermediate high, and 8 students (40\%) received a rating of advanced low. Further comparisons of pretest and posttest SOPI scores revealed that all 20 students maintained or improved their $L 2$ oral proficiency after the one-semester study-abroad program. As seen in Table $6,5(25 \%)$ of the 20 students made a gain of +2 on their pretest to posttest SOPI scores. A total of 11 students (55\%) made a gain of +1 , whereas 4 students (20\%) did not experience a gain. A paired-samples $t$-test was then performed to determine if the difference between the students' pretest and posttest SOPI scores was significant. The results of the $t$-test revealed that the difference was indeed significant $(t=-6.842, d f=19, p=.000$ ). The study-abroad participants therefore improved in their $L 2$ speaking abilities after one semester of study in Madrid.

Table 6. Summary of Participant Pretest and Posttest SOPI Scores

\begin{tabular}{|c|l|l|l|}
\hline Student & ACTFL Oral Proficiency Level Pretest & ACTFL Oral Proficiency Level Posttest & Gain \\
\hline 1 & Intermediate Low & Intermediate Mid & +1 \\
\hline
\end{tabular}




\begin{tabular}{|c|l|l|l|}
\hline 2 & Intermediate Low & Intermediate Mid & +1 \\
\hline 3 & Intermediate Mid & Intermediate Mid & - \\
\hline 4 & Intermediate Mid & Intermediate Mid & - \\
\hline 5 & Intermediate Mid & Intermediate Mid & - \\
\hline 6 & Intermediate Mid & Intermediate Mid & - \\
\hline 7 & Intermediate Mid & Intermediate High & +1 \\
\hline 8 & Intermediate Mid & Intermediate High & +1 \\
\hline 9 & Intermediate Mid & Intermediate High & +1 \\
\hline 10 & Intermediate Mid & Intermediate High & +1 \\
\hline 11 & Intermediate Mid & Intermediate High & +1 \\
\hline 12 & Intermediate Mid & Intermediate High & +1 \\
\hline 13 & Intermediate Mid & Advanced Low & +2 \\
\hline 14 & Intermediate Mid & Advanced Low & +2 \\
\hline 15 & Intermediate Mid & Advanced Low & +2 \\
\hline 16 & Intermediate Mid & Advanced Low & +2 \\
\hline 17 & Intermediate Mid & Advanced Low & +2 \\
\hline 18 & Intermediate High & Advanced Low & +1 \\
\hline 19 & Intermediate High & Advanced Low & +1 \\
\hline 20 & Intermediate High & Advanced Low & +1 \\
\hline
\end{tabular}

Note. SOPI = simulated oral proficiency interview.

\section{Research Question 4: Does Motivation Predict the Amount of Student Interaction With} the L2 Culture?

Simultaneous multiple regression analysis was performed to determine the significant predictors of student interaction with the $\mathrm{L} 2$ culture. The students' raw scores on the Integrative Motivation and Instrumental Motivation subscales were entered as the independent, predictor variables, and LCP scores were entered as the dependent variable. The prediction for student interaction is presented in Table $\mathbf{7}$. Shown in Table $\mathbf{7}$ are the following: (a) the Pearson correlation of the predictor with the outcome measure $(r)$, (b) the standardized regression coefficient $(\beta)$, (c) the $t$-statistic indicating the significance of the standardized regression coefficient $(t)$, and (d) the $p$-value of the $t$-statistic. The multiple regression model was significant $R^{2}=.46, F(2,17)=$ $7.14, p=.006$.

Table 7. Simultaneous Multiple Regression Model Predicting Student Interaction with the Second Language Culture

\begin{tabular}{|l|l|l|l|l|}
\hline Variable & $\boldsymbol{r}$ & $\beta$ & $\boldsymbol{t}$ & $\boldsymbol{p}$ \\
\hline Integrative Motivation & .675 & .667 & 3.660 & .002 \\
\hline Instrumental Motivation & -.168 & -.039 & -0.213 & .834 \\
\hline
\end{tabular}

The results of the regression analysis indicated that students with higher integrative motivation interacted more with the L2 culture than did the students with lower integrative motivation. As indicated in Table 7 , integrative motivation ( $\beta=.667, t=3.660, p=.002$ ) was the single significant predictor of student interaction with the $L 2$, accounting for $45.56 \%$ of the variance of the students' LCP scores. Instrumental motivation $(\beta=-.039, t=-$ $0.213, p=.834$ ) was not identified as a significant predictor of student interaction. 
Research Question 5: Does the Amount of Student Interaction With the L2 Culture Relate to Gains in L2 Oral Proficiency After Participation in a One-Semester Study-

\section{Abroad Program?}

Regression analysis was conducted to determine if there was a significant relationship between student interaction with the target language culture and gains in L2 speaking proficiency. The students' raw LCP scores were entered as the independent, predictor variable. Their SOPI gains were entered as the dependent variable. The prediction for SOPI gains is indicated in Table 8.

Table 8. Regression Model Predicting Pretest to Posttest SOPI Gains

\begin{tabular}{|l|l|l|l|l|}
\hline Variable & $\boldsymbol{r}$ & $\beta$ & $\boldsymbol{t}$ & $\boldsymbol{p}$ \\
\hline Language Contact & .693 & .693 & 4.080 & .001 \\
\hline Profile Score & & & & \\
\hline
\end{tabular}

Note. SOPI = simulated oral proficiency interview.

The regression model was significant $R^{2}=.48, F(1,18)=16.64, p=.001$. LCP scores $(\beta=.693, t=4.080, p=.001)$ were identified as a significant predictor. The amount of student interaction with the L2 culture (LCP scores) was a significant factor in language improvement, accounting for $48 \%$ of the variance of pretest to posttest SOPI gains.

\section{DISCUSSION}

To answer the first research question, descriptive statistics confirmed that the study-abroad participants were studying Spanish as an L2 for both integrative and instrumental reasons. The students reported an interest in speaking with NSs both in the United States and in other Spanish-speaking regions (integrative motivation) as two of the most important reasons for taking Spanish courses. Most of the students were also interested in using their Spanish for future travel (integrative motivation). In addition, almost all participants expressed an interest in the pragmatic benefits of Spanish language studies (instrumental motivation), reporting that it was important for them to know Spanish in order to enhance future career opportunities. The students' responses to an open-ended item on the pretest questionnaire (see Item 30 in Appendix B) further confirmed their interest in both integrative and instrumental aspects of studying Spanish. For instance, 5 students mentioned the importance of having knowledge of Spanish in order to gain a competitive edge in a global job market (instrumental motivation). These study-abroad participants reiterated their interest in becoming fluent in Spanish in order to be able to communicate with NSs, and, at the same time, expressed their desire to use the language for future travel to Spanish-speaking countries (integrative motivation).

The second research question examined the amount of student contact with the Spanish language outside of class through participation in speaking, writing, reading, and listening activities. The results of the LCP indicated that the students participated in these activities for an average of 60.68 hours per week $(M=60.68, S D=24.98)$. This result demonstrates that most of the students took advantage of the study-abroad context to use their Spanish outside of class to interact with the L2 culture. They reported speaking Spanish with their host families, with Spanish friends, and with their language exchange partners. They also reported using Spanish in bars and restaurants and while shopping or making travel plans. The participants further described, although to a lesser extent, having engaged in other Spanish language activities as well. They reported, for example, listening to music, watching television, reading email and Internet Web sites, and reading print media in Spanish.

At first glance, it was encouraging for the researcher to note that speaking Spanish with NSs or fluent speakers was the highest ranked item on the LCP, which suggested that the students had indeed invested a substantial amount of time communicating with NSs in Spanish. However, the high standard deviation on this item revealed a significant variation in the number of hours per week that the students were engaged in speaking activities in 
Spanish. The students' responses on Item 1 of the LCP yielded scores ranging from 3.5 to 42 hours per week. This result suggests that although some participants spent a considerable amount of time interacting with NSs, there were numerous others who did not take advantage of the study-abroad context to participate in the kinds of speech acts that foster L2 acquisition (Batstone, 2002; Collentine \& Freed, 2004; Segalowitz \& Freed, 2004; Swain, 1985, 1995, 2000). Student comments on the LCP further confirmed this situation. Out of the 20 participants, 10 mentioned that it was difficult to meet and interact with NSs. As with study-abroad participants in other recent studies (Allen \& Herron, 2003; Ife, 2000; Kinginger, 2008; Magnan \& Back, 2007), these students expressed regret over not having established a stronger social network of NSs with whom to interact.

The third research question investigated whether the participants improved their L2 oral proficiency after the one-semester study-abroad program. A paired-samples $t$-test revealed that the study-abroad participants made significant improvement on the pretest to posttest SOPI, with 16 out of the 20 students experiencing a gain of at least +1 on the ACTFL Proficiency Scale and 4 students showing no improvement in their spoken Spanish. The results of this third research question confirm recent studies suggesting that students can indeed improve their L2 oral proficiency during a one-semester study-abroad program (Magnan \& Back, 2007; Segalowitz \& Freed, 2004). Segalowitz and Freed (2004) reported that their study-abroad group made significant gains on an OPI. A total of 12 out of 22 study-abroad students experienced a gain of +1 on their preprogram to postprogram OPI, whereas 5 out of the 18 at-home students made a gain of +1 . There was also evidence of significant $L 2$ development among participants in Magnan and Back's (2007) study in which 12 out of 20 study-abroad participants showed improvement on a pretest to posttest OPI.

As did several of the participants in the Kinginger (2008) and Magnan and Back (2007) studies, a number of students in the present investigation attributed their speaking improvement to time spent with their host families. A few students said that speaking with their families gave them opportunities to practice their Spanish without the fear of making mistakes. Another student mentioned that numerous conversations with her host mother gave her the confidence to speak with other NSs. In contrast, 2 students commented on negative experiences with their host families. For 1 student it was difficult to speak Spanish at home, even with her host mother, because she had roommates from the United States. Another student mentioned that her host parents did not interact much with her. These comments address the concerns of Rivers (1998), Wilkinson (1998), Knight and Schmidt-Rinehart (2002), Isabelli-García (2006), Kinginger (2008), and Schmidt-Rinehart and Knight (2004). These investigators reported on study-abroad students who experienced few meaningful opportunities to speak the target language with their host families.

In addition to the participants' comments, data from the LCP also suggest that there was a relationship between the students' housing arrangements and their preprogram to postprogram language development. Out of the 16 students who improved on the SOPI, 15 students lived with host families. In contrast, 3 out of the 4 students who did not improve on the pretest to posttest SOPI lived in private apartments with roommates from the United States. Despite some researchers' concerns that living with NSs might not contribute to the kind of improvement in speaking that one would expect (Allen \& Herron, 2003; Magnan \& Back, 2007; Rivers, 1998; Segalowitz \& Freed, 2004; Wilkinson, 1998), the results of the present study suggest that living with host families is an important component of the study-abroad experience.

The results of the fourth research question emphasize the importance of integrative motivation in the L2 acquisition process (Dörnvei \& Clément, 2000; Dörnyei \& Schmitt, 2001; Gardner, 1985, 2000; Masgoret \& Gardner, 2003). Here, the researcher addressed the role of motivation in predicting student interaction with the L2 culture. Simultaneous multiple regression analysis identified integrative motivation as a significant predictor of student interaction with the $L 2$. The results demonstrate that study-abroad students with higher integrative motivation had more contact with the Spanish language outside of class - through participation in speaking, reading, writing, and listening activities - than did the students with lower integrative motivation. The issue of 
whether this student interaction had a positive effect on the students' speaking proficiency was addressed in the fifth and final research question.

The fifth research question examined the relationship between student interaction with the L2 culture and preprogram to postprogram language gain. Regression analysis identified a significant relationship between the amount of student contact with the Spanish language and improvement on the pretest to posttest SOPI.

As Kinginger (2008) found in her research, the students in the present study who reported having the most contact with the L2 culture developed their speaking abilities more than did the students who did not have as much contact. Further examination of the students' individual LCP scores and their pretest to posttest SOPI ratings provides even more robust evidence of this relationship. The 5 students who made gains of +2 on their preprogram to postprogram SOPI scores reported participating in out-of-class language contact activities for an average of 92.30 hours per week. The 11 students who had a gain of +1 reported an average of 52.36 hours per week for out-of class language activities, whereas the 4 students who did not experience a gain on the pretest to posttest SOPI had an average of 43.75 hours per week. All together, these results confirm the assumption that study-abroad participants can have significant contact with the L2 culture and that this contact, in turn, supports the development of oral proficiency (Brecht et al., 1995; Isabelli-García, 2006; Magnan \& Back, 2007; Segalowitz \& Freed, 2004).

Segalowitz and Freed (2004) discovered, however, that despite significant gains on a pretest to posttest OPI, the amount of out-of-class language contact did not have a significant effect on their study-abroad participants' speaking improvement. The authors argued that the one-semester study-abroad experience might not have provided the students with enough time to make significant language progress and that the amount of language contact might have been insufficient to foster language development. It is important to note that the studyabroad participants in Segalowitz and Freed's study reported participating in out-of-class language activities for an average of 18 hours per week. In contrast, the study-abroad students in the present investigation reported participating in similar out-of-class language activities for an average of 60.68 hours per week. It might be that the greater amount of contact with NSs gave the participants in the present study the requisite time-on-task to improve their spoken Spanish.

\section{RECOMMENDATIONS}

The present investigation supports the value of a one-semester study-abroad program and, at the same time, highlights the complexities of this experience. The results confirm that student motivation and interaction are important factors in predicting success in a study-abroad context. The following recommendations, presented within the context of the Standards for Foreign Language Learning in the 21st Century (NSFLEP, 1999), seek to forge a strong connection between the at-home language learning experience and that of study abroad.

With regard to motivation, instructors should attempt to incorporate activities into the at-home curriculum that foster students' integrative motivation. Study-abroad program directors and instructors can then continue to promote integrative motivation through similar activities within the study-abroad environment. At-home and study-abroad students, for example, might interview NSs or near-native speakers of the L2 and report on the results of their interviews in class (Standards addressed are 1.1, 1.2, 1.3, 2.1, 3.1, 3.2, 4.2, and 5.1). These activities allow learners to use the target language to explore the linguistic and cultural differences of the $L 2$ culture and to reflect on the similarities and differences between their own culture and the L2 culture (Hernández, 2006). At the same time, instructors can provide students with frequent and sustained opportunities to use the L2 outside of class through participation in a language exchange program. A common practice in the study-abroad context, language exchange programs allow students to practice the target language with a language exchange partner in a semicontrolled environment (Standards 1.1, 1.2, 2.1, 2.2, 3.2, and 5.1). 
The integration of authentic materials into at-home and study-abroad classrooms provides students with meaningful opportunities to interact with the $L 2$ culture and can further enhance their integrative motivation. At the same time, the use of the Internet, radio, L2 satellite television, and different forms of computer-mediated communication - such as the social software program Skype (http://www.skype.com; Coffey \& Banhidi, 2007), email, or chat rooms-all provide an interactive framework for incorporating Culture Standards 2.1 and 2.2 into language instruction. Using Skype, for example, enables students to use the target language as a tool to exchange information with NSs of different L2 communities (Standards 1.1, 1.2, 1.3, 3.1, 3.2, and 5.1). The integration of a service-learning component, whether in an at-home formal classroom or in a study-abroad context, also allows students to interact with NSs of the L2 culture (Caldwell, 2007; Hellebrandt \& Varona, 1999; Kiely \& Nielson, 2003) and is consistent with the goals expressed in the Standards.

The results of the pretest questionnaire indicated that the students were interested in instrumental factors for studying Spanish (see Items 20, 24, 27, and 29 in Appendix C). The high mean score ( $M=10.70, S D=1.92$ ) on the Instrumental Motivation subscale suggests that it is important to attend to this aspect of students' motivation. Instructors should invite guest speakers to the classroom to address such issues as career opportunities, the current and future status of the target language in the United States and abroad, and current events (Standards 1.1, 1.2, 3.1, 3.2, and 5.1). Within the study-abroad environment, a greater number of opportunities should also be provided for students to develop advanced-level language abilities through participation in structured internship and volunteer activities (Standards 1.1, 1.2, 1.3, 3.1, 3.2, 5.1, and 5.2).

The high standard deviation on the LCP $(M=60.68, S D=24.98)$ suggests that some students did not take advantage of the study-abroad context in order to participate in the kinds of speech acts that contribute to $L 2$ acquisition growth. This finding is consistent with those of recent studies (Kinginger, 2008; Magnan \& Back, 2007; Segalowitz \& Freed, 2004). As did the participants in Kinginger's (2008) study, the participants in the present investigation expressed an interest in using the target language to connect with NSs outside the classroom. As Kinginger observed, study-abroad students are often unaware, however, that the development of advanced language competence represents a long-term effort requiring a serious investment of time. Studyabroad directors, therefore, should discuss with students the importance of social interaction with NSs as a key factor in the development of their speaking proficiency. During orientation, participants should be provided with social events that allow them to meet NSs and practice their speaking and listening abilities, as well as to develop important sociolinguistic and pragmatic knowledge of the L2 (Standards 1.1, 1.2, 1.3, 2.1, 2.2, 3.2, 4.1, 4.2, and 5.1). Study-abroad program staff should, as Kinginger (2008) and Magnan and Back (2007) suggested, further guide study-abroad students in developing appropriate communicative and cultural strategies (Paige, Cohen, Kappler, Chi, \& Lassegard, 2006) and provide them with predeparture, in-country, and post-studyabroad sessions fostering awareness of language learning and use (Kinginger, 2008). Administrators should also assist students in establishing realistic goals and expectations for their study-abroad experience and discuss with them the value of participating in extracurricular activities. To this end, a questionnaire should be administered to ask about students' hobbies and interests. Program staff should then attempt to assist students in establishing the appropriate contacts in order to pursue these activities (Standards 1.1, 1.2, 5.1, and 5.2).

Student responses on the LCP also indicated that it was difficult for them to meet and interact with NSs. Again, as part of study-abroad orientation, program staff should help students develop a strong social network of NSs. As Kinginger (2008) noted, students often require assistance in developing, valuing, and nurturing contacts with NSs. In addition, the data from the LCP suggest that the students who lived with host families made more significant preprogram to postprogram speaking improvement than did the students who lived in private apartments with roommates from the United States. The positive impact of host families reported here is an important finding because several recent studies (Magnan \& Back, 2007; Segalowitz \& Freed, 2004) have not found evidence of significant relationships among student interaction with the L2, living with host families, and 
the development of speaking proficiency. Study-abroad programs, therefore, should continue to encourage students to live with host families, given that this living environment seems to be an important factor in predicting improvement in L2 speaking performance. Furthermore, the participants' comments on the LCP indicate the need for study-abroad programs to examine how to enhance students' contact with their host families. In order to facilitate student interaction with their hosts, Raschio (2001) suggested that study-abroad program directors encourage the students to use the target language with their host families in specific research activities that, in turn, form an important component of their coursework (Standards 1.1, 1.2, 1.3, 2.1, 3.1, 3.2, 4.2 , and 5.1).

\section{CONCLUSION}

The present investigation is one of the most recent studies to examine the connections among student motivation, interaction with the L2, and speaking improvement on an SOPI. The results highlight three major points. First, students can improve their L2 speaking proficiency during a one-semester study-abroad program. Second, there is a positive relationship between students' integrative motivation and their interaction with the L2 culture. Third, student contact with the Spanish language has a significant effect on their speaking improvement. The data confirm the importance of focusing on at-home and study-abroad learning activities that foster students' integrative motivation and interaction with the $L 2$ culture.

This study has also demonstrated that future research is needed to provide greater insight into the nature of L2 learning in a study-abroad context. One question may be whether the self-reported measures in the second part of the pretest questionnaire (Motivation Index) and the posttest LCP are accurate representations of student motivation and subsequent contact with the Spanish language throughout the study-abroad experience. Future research should therefore supplement these quantitative studies with qualitative approaches, such as introspective participant diaries and interviews, which would allow the students to reflect on their interactions with NSs during the study-abroad experience. In addition, researchers should also consider using Skype as a tool to elicit spontaneous student reflections about their $L 2$ learning experiences. Obtaining these kinds of unrehearsed student observations might provide important information about the challenges that study-abroad participants encounter when communicating with NSs. Future research should also seek to assess the impact of interventions designed to enhance study-abroad students' use of language and culture strategies (Cohen \& Shively, 2007). In addition, future studies should compare the roles of motivation and interaction with the L2 in study-abroad and at-home contexts in order to enhance L2 learning in both environments. These studies should examine the relationships between motivation and other areas of language learning such as the acquisition of sociolinguistic and pragmatic competence. Because few studies have addressed the role of formal classroom learning within a study-abroad environment, researchers might begin to investigate how formal classroom instruction interacts with and shapes $L 2$ acquisition in the study-abroad context. It is clear that these avenues of research will foster greater achievement for all language learners in both study-abroad and at-home learning contexts.

\section{ACKNOWLEDGMENTS}

I wish to thank the College of Arts and Sciences, Department of Foreign Languages and Literatures, and the Office of International Education at Marquette University for their financial support. I would like to thank Paul García for his generous support and guidance in preparing this manuscript. My thanks to Katharine Burns for research assistance. I also thank the anonymous reviewers for their insightful comments and suggestions. A special thanks to the study-abroad students who participated in this project. 


\section{Appendices}

\begin{tabular}{|c|c|c|c|c|c|c|}
\hline Student & $\begin{array}{l}\text { Pretest } \\
\text { SOPI }\end{array}$ & $\begin{array}{l}\text { Posttest } \\
\text { SOPI }\end{array}$ & $\begin{array}{l}\text { Housing } \\
\text { Arrangement }\end{array}$ & $\begin{array}{l}\text { Integrative } \\
\text { Motivation }\end{array}$ & $\begin{array}{l}\text { Instrumental } \\
\text { Motivation }\end{array}$ & LCP \\
\hline 1 & Int. Low & Int. Mid & Family & 26 & 11 & 94.50 \\
\hline 2 & Int. Low & Int. Mid & Family & 21 & 12 & 45.50 \\
\hline 3 & Int. Mid & Int. Mid & $\begin{array}{l}\text { Apartment with non- } \\
\text { Spanish }\end{array}$ & 23 & 11 & 66.50 \\
\hline 4 & Int. Mid & Int. Mid & $\begin{array}{l}\text { Apartment with non- } \\
\text { Spanish }\end{array}$ & 21 & 12 & 42.00 \\
\hline 5 & Int. Mid & Int. Mid & Family & 23 & 12 & 35.00 \\
\hline 6 & Int. Mid & Int. Mid & $\begin{array}{l}\text { Apartment with non- } \\
\text { Spanish }\end{array}$ & 24 & 9 & 31.50 \\
\hline 7 & Int. Mid & Int. High & Family & 22 & 12 & 49.00 \\
\hline 8 & Int. Mid & Int. High & Family & 25 & 11 & 56.00 \\
\hline 9 & Int. Mid & Int. High & Family & 27 & 10 & 59.00 \\
\hline 10 & Int. Mid & Int. High & Family & 26 & 12 & 52.50 \\
\hline 11 & Int. Mid & Int. High & Family & 21 & 11 & 35.00 \\
\hline 12 & Int. Mid & Int. High & Family & 24 & 12 & 45.50 \\
\hline 13 & Int. Mid & Adv. Low & Family & 25 & 4 & 77.00 \\
\hline 14 & Int. Mid & Adv. Low & Family & 27 & 12 & 115.50 \\
\hline 15 & Int. Mid & Adv. Low & Family & 26 & 9 & 108.50 \\
\hline 16 & Int. Mid & Adv. Low & Family & 25 & 10 & 70.00 \\
\hline 17 & Int. Mid & Adv. Low & Family & 27 & 11 & 90.50 \\
\hline 18 & Int. High & Adv. Low & Family & 23 & 12 & 56.00 \\
\hline 19 & Int. High & Adv. Low & Family & 23 & 9 & 31.50 \\
\hline 20 & Int. High & Adv. Low & $\begin{array}{l}\text { Apartment with non- } \\
\text { Spanish }\end{array}$ & 26 & 12 & 52.50 \\
\hline
\end{tabular}

- Note. $\mathrm{LCP}=$ Language Contact Profile; SOPI = simulated oral proficiency interview .

\section{APPENDIX B Student Questionnaire}

Part I. Student Background Information

1. Gender: a. Male b. Female

2. Age:

3. What is your native language?
a. English
b. Spanish
c. Other

4. What language do you speak at home?
a. English
b. Spanish
c. Other

5. Academic status:
a. Freshman
b. Sophomore
c. Junior
d. Senior
e. Other

6. Academic major:

7. Cumulative grade point average in all undergraduate courses:

8. Number of total semesters studying Spanish at the college level

(including this semester):

9. Names of all Spanish courses taken at MU prior to Fall 2007:

10. Name of Fall 2007 Spanish courses: 
12. Number of semesters studying Spanish at the high school level:

13. Have you participated in a study abroad program?
a. Yes
b. No

14. Do you plan to participate in a study abroad program in the future?
a. Yes
b. No

15. Do you plan to study toward a major in Spanish?
a. Yes
b. No

16. Do you plan to study toward a minor in Spanish?
a. Yes
b. No

Part II. Language Learning Survey

Use the following scale to indicate the degree to which the following reasons for studying Spanish are important to you.

Rating Scale:

$0=$ not important

$1=$ slightly important

$2=$ moderately important

3 = very important

I am taking Spanish because

17. I want to use Spanish when I travel to a Spanish-speaking region.
0
1
2
3

18. I want to be able to converse with Spanish speakers in the United States.
0
1
2
3

19. I am interested in Hispanic culture, history, or literature.

$\begin{array}{llll}0 & 1 & 2 & 3\end{array}$

20. I feel that Spanish may be helpful in my future career.
0
1
23

21. I want to be able to use it with Spanish-speaking friends/acquaintances.
0
1
2
3

22. I want to be able to speak more languages than just English.
0
1
2
3

23. I want to learn about another culture to understand the world better.

$\begin{array}{llll}0 & 1 & 2 & 3\end{array}$

24. Spanish may make me a more qualified job candidate.

$\begin{array}{llll}0 & 1 & 2 & 3\end{array}$

25. I think foreign language study is part of a well-rounded education.

$\begin{array}{llll}0 & 1 & 2 & 3\end{array}$

26. I feel that Spanish is an important language in the world.
0
1
2
3

27. I feel that knowledge of Spanish will give me an edge in competing with others.

$\begin{array}{llll}0 & 1 & 2 & 3\end{array}$

28. I want to be able to communicate with native speakers of Spanish.

$\begin{array}{llll}0 & 1 & 2 & 3\end{array}$

29. I feel that Spanish will enhance my résumé or C.V.

$\begin{array}{llll}0 & 1 & 2 & 3\end{array}$

30. List additional reasons for taking Spanish courses: 


\section{APPENDIX C Language Contact Profile}

Please indicate the courses that you are taking in the spring 2008 semester:

COURSE NAME

COURSE NUMBER

Indicate the situation that best describes your living arrangement in Spain:

a. ___ I lived with a Spanish-speaking host family.

b. ___ I lived in an apartment with native or fluent Spanish speaker(s).

c. ___ I lived in an apartment with others who were NOT native or fluent Spanish speakers.

d. Other:

1. Circle the average number of hours each week you spent speaking in Spanish outside of class with native or fluent Spanish speakers during this semester.

$\begin{array}{lrrrrrrrrrr}0 & .5 & 1 & 1.5 & 2 & 2.5 & 3 & 3.5 & 4 & 4.5 & 5 \\ \begin{array}{l}5.5 \\ 6\end{array} & 6.5 & 7 & 7.5 & 8 & 8.5 & 9 & 9.5 & 10 & 10.5 & 11 \\ \begin{array}{l}11.5 \\ 12\end{array} & 12.5 & 13 & 13.5 & 14 & 14.5 & 15 & 15.5 & 16 & 16.5 & 17 \\ \begin{array}{l}17.5 \\ 18\end{array} & 18.5 & 19 & 19.5 & 20 & 20.5 & 21 & 21.5 & 22 & 22.5 & 23 \\ 23.5 & & & & & & & & & & \\ 24 & 24.5 & 25 & 25.5 & 26 & 26.5 & 27 & 27.5 & 28 & 28.5 & 29 \\ 29.5 & & & & & & & & & & \end{array}$

2. Circle the average number ofhours each week you spent reading Spanish newspapers outside of class during this semester.

\section{REFERENCES}

ACTFL (American Council on the Teaching of Foreign Languages). (1999). ACTFL proficiency guidelines-Speaking. Hastings-on-Hudson, NY : Author.

Allen, H., \& Herron, C. (2003). A mixed-methodology investigation of the linguistic outcomes of summer study abroad. Foreign Language Annals, 36, 370- 385.

Barron, A. (2003). Acquisition in interlanguage pragmatics: Learning how to do things with words in a study abroad context. Amsterdam : Benjamins.

Barron, A. (2006). Learning to say "you" in German: The acquisition of sociolinguistic competence in a study abroad context. In M. DuFon \& E. Churchill (Eds.), Language learners in study abroad contexts (pp. 59-88). Clevedon, UK : Multilingual Matters.

Batstone, R. (2002). Contexts of engagement: A discourse perspective on "intake" and "pushed output." System, 30, 1- 14.

Brecht, R., Davidson, D., \& Ginsberg, R. (1993). Predictors of foreign language gain during study abroad. Washington, DC : National Foreign Language Center.

Brecht, R., Davidson, D., \& Ginsberg, R. (1995). Predictors of foreign language gain during study abroad. In B. F. Freed (Ed.), Second language acquisition in a study abroad context (pp. 37-66). Amsterdam : Benjamins.

Brecht, R., \& Robinson, J. (1995). On the value of formal instruction in study abroad: Student reactions in context. In B. F. Freed (Ed.), Second language acquisition in a study abroad context (pp. 317-334). Amsterdam : Benjamins.

Caldwell, W. (2007). Taking Spanish outside the box: A model for integrating service learning into foreign language study. Foreign Language Annals, 40, 463- 471.

Center for Applied Linguistics (1995). The Spanish speaking test. Washington , DC : Author. 
Center for Applied Linguistics (2006). Multimedia rater training program (MRTP)—Spanish version. Washington , DC : Author.

Coffey, C., \& Banhidi, J. (2007, November). Conversation goes global: Social software takes language learning to a new level. Paper presented at the American Council on the Teaching of Foreign Languages Conference , San Antonio, TX.

Cohen, A. D., \& Shively, R. L. (2007). Acquisition of requests and apologies in Spanish and French: Impact of study abroad and strategy-building intervention. Modern Language Journal, 91, 189- 212.

Collentine, J. (2004). The effects of learning contexts on morphosyntactic and lexical development. Studies in Second Language Acquisition, 26, 227- 248.

Collentine, J., \& Freed, B. F. (2004). Learning context and its effects on second language acquisition: Introduction. Studies in Second Language Acquisition, 26, 153- 171.

Deci, E. L. (1975). Intrinsic motivation. New York : Plenum.

Deci, E. L., \& Ryan, R. M. (1985). Intrinsic motivation and self-determination in human behavior. New York : Plenum.

Díaz-Campos, M. (2004). Context of learning in the acquisition of Spanish second language phonology. Studies in Second Language Acquisition, 26, 249- 273.

Díaz-Campos, M. (2006). The effect of style in second language phonology: An analysis of segmental acquisition in study abroad and regular-classroom students. In C. A. Klee \& T. L. Face (Eds.), Selected proceedings of the 7 th conference on the acquisition of Spanish and Portuguese as first and second languages (pp. 26-39). Somerville, MA : Cascadilla Proceedings Project.

Dörnyei, Z., \& Clément, R. (2000, April). Motivational characteristics of learning different target languages: Results of a nationwide survey. Paper presented at the American Association for Applied Linguistics Conference, Vancouver, Canada .

Z. Dörnyei, \& R. Schmitt (Eds.). (2001). Motivation and second language acquisition. Honolulu : University of Hawai'i Press.

Douglass, K. (2006). From the learner's perspective: A case study on motives and study abroad. In S. Wilkinson (Ed.), Insights from study abroad for language programs (pp. 116-133). Boston : Heinle.

Duperron, L. (2006). Study abroad and the second language acquisition of tense and aspect in French: Is longer better? In S. Wilkinson (Ed.), Insights from study abroad for language programs (pp. 45- 71). Boston : Heinle.

Ely, C. M. (1986). Language learning motivation: A descriptive and causal analysis. Modern Language Journal, 70, 28- 35.

Freed, B. F. (1990). Language learning in a study abroad context: The effects of interactive and non-interactive out-of-class contact on grammatical achievement and oral proficiency. In J. Atlatis (Ed.), Linguistics, language teaching and language acquisition: The interdependence of theory, practice and research (pp. 459-477). Georgetown University Round Table on Languages and Linguistics . Washington , DC : Georgetown University Press.

Freed, B. F. (1995). What makes us think that students who study abroad become fluent? In B. F. Freed (Ed.), Second language acquisition in a study abroad context (pp. 123-148). Amsterdam : Benjamins.

Freed, B. F., Dewey, D. P., Segalowitz, N., \& Halter, R. (2004). The language contact profile. Studies in Second Language Acquisition, 26, 349- 356.

Gardner, R. C. (1985). Social psychology and second language learning: The role of attitudes and motivation. London : Edward Arnold.

Gardner, R. C. (2000). Correlation, causation, motivation, and second language acquisition. Canadian Psychology, 41, 10- 24.

Gardner, R. C., \& Lambert, W. E. (1959). Motivational variables in second language acquisition. Canadian Journal of Psychology, 13, 266- 272.

Gardner, R. C., \& Lambert, W. E. (1972). Attitudes and motivation in second language learning. Rowley, MA : Newbury. 
Ginsburg, R. B., \& Miller, L. (2000). What do they do? Activities of students during study abroad. In R. D. Lambert \& E. Shohamy (Eds.), Language policy and pedagogy: Essays in honor of A. Ronald Walton (pp. 237- 261). Philadelphia : Benjamins.

J. Hellebrandt, \& L. T. Varona (Vol. Eds.), Zlotkowski, E. (Series Ed.). (1999). Construyendo puentes (building bridges): Concepts and models for service-learning in Spanish. Washington , DC : American Association for Higher Education.

Hernández, T. (2006). Integrative motivation as a predictor of success in the intermediate foreign language classroom. Foreign Language Annals, 39, 605- 617.

Ife, A. (2000). Language learning and residence abroad: How self-directed are students Language Learning Journal, 22, 30- 37.

Isabelli, C. (2004). Study abroad for advanced foreign language majors: Optimal duration developing complex structures. In H. Byrnes \& H. Maxim (Eds.), Advanced foreign language learning: A challenge to college programs (pp. 114-130). Boston : Heinle.

Isabelli, C. A. (2007). Development of the Spanish subjunctive by advanced learners: Study abroad followed by at-home instruction. Foreign Language Annals, 40, 330- 341.

Isabelli-García, C. (2006). Study abroad social networks, motivations and attitudes: Implications for second language acquisition. In M. DuFon \& E. Churchill (Eds.), Language learners in study abroad contexts (pp. 231-258). Clevedon, UK : Multilingual Matters.

Kiely, R., \& Nielson, D. (2003). International service learning: The importance of partnerships. Community College Journal, 73, 39- 41.

Kinginger, C. (2008). Language learning in study abroad: Case studies of Americans in France. Modern Language Journal, 92, 1- 131.

Knight, S. M., \& Schmidt-Rinehart, B. C. (2002). Enhancing the homestay: Study abroad from the host family's perspective. Foreign Language Annals, 35, 190- 201.

Kuo, J., \& Jiang, X. (1997). Assessing the assessments: The OPI and the SOPI. Foreign Language Annals, 30, 503- 512.

Lafford, B. A. (1995). Getting into, through and out of a survival situation: A comparison of communicative strategies used by students studying Spanish-Abroad and "at home." In B. F. Freed (Ed.), Second language acquisition in a study abroad context (pp. 97-121). Amsterdam : Benjamins.

Lafford, B. A. (2004). The effect of the context of learning on the use of communication strategies by learners of Spanish as a second language. Studies in Second Language Acquisition, 26, 201- 225.

Lafford, B. A., \& Collentine, J. (2006). The effects of study abroad and classroom contexts on the acquisition of Spanish as a second language. In R. Salaberry \& B. A. Lafford (Eds.), The art of teaching Spanish: Second language acquisition from research to praxis (pp. 103-126). Washington, DC : Georgetown University Press.

Lapkin, S., Hart, D., \& Swain, M. (1995). A Canadian interprovincial exchange: Evaluating the linguistic impact of a three-month stay in Quebec. In B. F. Freed (Ed.), Second language acquisition in a study abroad context (pp. 67-94). Amsterdam : Benjamins.

Magnan, S. S. (1986). Assessing speaking proficiency in the undergraduate curriculum: Data from French. Foreign Language Annals, 19, 429-437.

Magnan, S. S., \& Back, M. (2006). Requesting help in French: Developing pragmatic features during study abroad. In S. Wilkinson (Ed.), Insights from study abroad for language programs (pp. 22-44). Boston : Heinle.

Magnan, S. S., \& Back, M. (2007). Social interaction and linguistic gain during study abroad. Foreign Language Annals, 40, 43-61.

Masgoret, A. M., \& Gardner, R. C. (2003). Attitudes, motivation, and second language learning: A meta-analysis of studies conducted by Gardner and associates. Language Learning, 53, 123- 163.

Meara, P. (1994). The year abroad and its effects. Language Learning Journal, 10, 32- 38.

Miller, L., \& Ginsberg, R. B. (1995). Folklinguistic theories of language learning. In B. F. Freed (Ed.), Second language acquisition in a study abroad context (pp. 293-315). Amsterdam : Benjamins. 
NSFLEP (National Standards in Foreign Language Education Project). (1999). Standards for foreign language learning in the 21st century. Yonkers, NY : Author.

Oxford, R. L., \& Shearin, J. (1994). Language learning motivation: Expanding the theoretical framework. Modern Language Journal, 78, 12- 28.

Paige, R. M., Cohen, A., Kappler, B., Chi, J., \& Lassegard, J. (2006). Maximizing study abroad ( 2nd ed.). Minneapolis : Center for Advanced Research on Language Acquisition, University of Minnesota.

Ramage, K. (1990). Motivational factors and persistence in foreign language study. Language Learning , 40, 182- 219.

Raschio, R. A. (2001). Integrative activities for the study-abroad setting. Hispania, 84, 534- 541.

Regan, V. (1995). The acquisition of sociolinguistic native speech norms: Effects of a year abroad on second language learners of French. In B. F. Freed (Ed.), Second language acquisition in a study abroad context (pp. 245- 268). Amsterdam : Benjamins.

Regan, V. (2003). Sociolinguistics and language learning in a study abroad context. Frontiers: The Interdisciplinary Journal of Study Abroad, 4, 61- 90.

Rivers, W. (1998). Is being there enough? The effects of homestay placement on language gain during study abroad. Foreign Language Annals, 31, 492- 500.

Rodríguez, S. (2001). The perception of requests in Spanish by instructed learners of Spanish in second-and foreign-language contexts: A longitudinal study of acquisition patterns. Unpublished doctoral dissertation, Indiana University, Bloomington .

Segalowitz, N., \& Freed, B. F. (2004). Context, contact, and cognition in oral fluency acquisition: Learning Spanish in at home and study abroad contexts. Studies in Second Language Acquisition, 26, 173- 199.

Schmidt-Rinehart, B. C., \& Knight, S. M. (2004). The homestay component of study abroad: Three perspectives. Foreign Language Annals, 37, 254- 262.

Swain, M. (1985). Communicative competence: Some roles of comprehensible input and comprehensible output in its development. In S. Gass \& C. Madden (Eds.), Input in second language acquisition. Cambridge , MA : Newbury.

Swain, M. (1995). Three functions of output in second language learning. In G. Cook \& B. Seidlhofer (Eds.), Principle and practice in applied linguistics: Studies in honour of H. G. Widdowson (pp. 124-144). Oxford : Oxford University Press.

Swain, M. (2000). The output hypothesis and beyond: Mediating acquisition through collaborative dialogue. In J. Lantolf (Ed.), Sociocultural theory and second language learning (pp. 97-114). Oxford : Oxford University Press.

Ushioda, E. (1998). Effective motivational thinking: A cognitive theoretical approach to the study of language learning motivation. In E. A. Soler \& V. C. Espurz (Eds.), Current issues in English language methodology (pp. 77-89). Castelló de la Plana, Spain : Universitate Jaume I.

Ushioda, E. (2001). Language learning at university: Exploring the role of motivational thinking. In Z. Dörnyei \& R. Schmidt (Eds.), Motivation and second language acquisition (Tech. Rep. No. 23, pp. 93-125). Honolulu : University of Hawai'i, Second Language Teaching and Curriculum Center.

Wilkinson, S. (1998). Study abroad from the participants' perspective: A challenge to common beliefs. Foreign Language Annals, 31, 23-39.

Wilkinson, S. (2002). The omnipresent classroom during summer study abroad: American students in conversation with their French hosts. Modern Language Journal, 86, 157- 173.

Williams, M., \& Burden, R. (1997). Psychology for language teachers. Cambridge : Cambridge University Press. 